\title{
Suggestions on the Development of Agricultural Insurance in Jilin Province
}

\author{
Wenbo Sun \\ School of Finance \\ Jilin Business and Technology College \\ Jilin, China
}

\begin{abstract}
In 2007, agricultural insurance as an important agenda in building a new socialist countryside in the central No. 1 files, and Jilin province is determined one of the six pilot province agriculture in the files. This article analysis the present situation of Jilin province which is under the national support and the participation of farmers that agricultural insurance healthy rapidly develops. But problems appeared in the developing in this paper, the existing problems put forward the measures to solve one by one.
\end{abstract}

Keywords-agricultural insurance; Jilin province; countermeasures

\section{INTRODUCTION}

Agriculture as the foundation of the national economy pillar industry, it has also been referred to as "weak industry" at the same time, and it is restricted by the severe to withstand natural disasters, such as flooding in the south, the drought in the north. In such cases, the development of agricultural insurance has become a top priority. Agricultural insurance can effectively reduce the loss caused by disasters, avoid risks and reduce the pressure of the government's support. Jilin province is a big agricultural province, the national important grain production base, and is also a disaster-prone province, and then agriculture grain production must be affected by natural disaster. Therefore, Jilin province speeds up the development of agricultural insurance to ensure the steady development of agriculture.

\section{The CuRrent Situation OF THE Agricultural INSURANCE IN JILIN PROVINCE}

In 2003, the Jilin Insurance Regulatory Commission put forward the development of the "three rural" comprehensive insurance which is pulled open the prelude of agricultural insurance. In 2004, Jilin Anhua agricultural insurance started to operate agricultural insurance business with the support of the China insurance regulatory commission. In April 2007, Jilin province have the honor to become the country's first carry out policy-oriented agricultural insurance which is one of the six pilot provinces, in these six provinces, Jilin province is the biggest insured agriculture area, insured proportion and farmers yield than the highest provinces. By the end of 2012, the number of Jilin insured farmers reached 2.01 million, accounting for $70 \%$ of the total farmers in the province. At the same time, the five traditional varieties of agricultural insurance of Jilin province like corn, rice, soybean, sunflower seeds, peanut, on the basis of the features have also developed agricultural insurance which have chili, ginseng, tobacco leaf, sika deer, and professional farms and so on. Insurance premium of ginseng, pepper and tobacco reach 11.8268 million Yuan in 2013, the total contracting an area of $196600 \mathrm{mu}$, the insured farmers reached 7551 peasant households, which claims 5173 peasant households, payment of RMB 7.5861 million Yuan.

\section{The EXISTING Problems IN THE DEVELOPMENT OF AGRICULTURAL INSURANCE IN JILIN PROVINCE}

\section{A. Difficult in collecting farmers paying and lower paying ratio}

The main targets of agricultural insurance are farmers and it provides farmers with a safe haven and avoids natural disasters. However, for farmers, because they did not receive a good education or lower education level, basic knowledge as well as the role of agricultural insurance and prevention is not clear, the farmers' understanding of agricultural insurance is not deeply, pay cost ratio is low.

According to a survey in Jilin Songyuan, although in recent years, natural disasters are frequent and bring to the farmers more severe losses, farmers capture puts the forehead is falling. The main reason in the following two aspects: one is because of lower farmers' incomes, their annual income is between 15000 Yuan and 15000 Yuan which are accounted for $29 \%$ of investigation number, and the number of annual income is above 30000 Yuan of accounts for only $10 \%$ of survey farmers. Many farmers are reluctant to spend money on the presence of uncertainty. The second is due to the lack of awareness of farmers to the agricultural insurance, and lead to poor performance of the actual security, the peasants did not meet the expectations. At present, the agricultural insurance in the insurance company is only a form of guarantee which cost without storage revenue, and farmers did not doubt about the issue before the insured, when suffered losses, damages and expected amount is hard to reach an agreement, so in recent years, farmers insurance will is not strong. 


\section{B. Single channels in agricultural insurance compensation}

In the survey we found that the current agricultural insurance of the insurance companies are generally require insurance claims to do transfer payment, cash payments are strictly prohibited. Such strict rules in the process of claim will produce certain problems, especially for regional remoter farmers. In 2013, for example, the set in the agricultural insurance business in the people's insurance company of Jilin province Tonghua branch, due to the farmers in remote areas, each household farmers' compensation amount from ten Yuan to several dozen Yuan and it involved hundreds of peasant households, they have no card, no bank account, at the request of the mandatory, hundreds of peasants, spending money back and forth to open a bank account, pay 5-10 Yuan account management fee each year, when they get the compensation amount has already left less, the manage compensate farmers will choose to give up.

\section{The lack of agricultural insurance professionals and lower quality}

Due too late in carrying out of the agricultural insurance and agricultural insurance risk is more special and complicated, so agricultural insurance have higher technical requirements. In the complex process of carrying out of Agricultural insurance in our country, agricultural insurance talents fault on the development of agricultural insurance also restricted to some extent, whether it really can carry on the research of agricultural insurance talent or play a role in the management of the personnel are scarce. Insurance technology is a crucial factor in the insurance business whether it is good or bad, and the need is to have professional knowledge in agriculture at the same time and insurance knowledge comprehensive and complex talents. at present, talent is scarce in Jilin province.

Since 2007, Jilin province as a national agricultural insurance pilot, nearly 2000 professionals engaged in agricultural insurance, and involved in the agricultural insurance has more than 3000 people, if the insurance is extended to drive the work of cadres, there will be more than 20000 people. These personnel management mode and management idea are quite different, and the familiarity to the agricultural insurance business is endless also and same, so the insurance of each link will appears some flaws, such as: "instead", "copy" and "false", and somewhere will be a fact and embezzlement premium phenomenon.

\section{RECOMMENDATIONS ON THE DEVELOPMENT OF JILIN PROVINCE AGRICULTURAL INSURANCE}

\section{A. Strengthen the propaganda, improving farmers' recognition of agricultural insurance}

How to effective propaganda agricultural insurance has also been the work of weaknesses in Jilin province agriculture insurance, and if it wants to ascend farmers' cognition of agricultural insurance, agricultural insurance benefit the people tendency will be more. It is considered how to use technology to strengthen the agricultural insurance propaganda, strengthen the peasants and the main content of agricultural insurance operation service mechanism of familiar. It reverses the farmers from fundamental thought understanding of agricultural insurance, let farmers from passive to active insurance, so as to effectively promote the premium collection work.

For farmers understand ability is limited, the problems of the insurance company can organize business backbone in farming season, came into the door, meticulous, patient with the interpretation of farmers to give farmers into a comparative calculation, clear insurance terms, to interest, let farmers to protect the rest assured.

\section{B. Developing new products, improving service levels}

Agriculture is an important industry related to national life, to develop agricultural insurance is to ensure the safety of food production, the insurance company will have to combined with the field survey, reasonable use of actuarial, develop characteristic agriculture insurance products for the farmers, according to the different characteristics of regional and planting to develop new danger to plant, setting reasonable premium as well as the compensation rate, to meet the requirements of farmers economic capability. To carry out the pork price index, for example, insurance and weather index insurance, credit insurance and so on a variety of new agricultural insurance coverage. Insurance companies to provide diversified services as well as to increase the investment of funds, combined with the country's fiscal subsidy policy, the benefits of the agricultural insurance play to the largest.

\section{Strengthen business training, improving personnel quality}

Agriculture insurance involves more professional, such as botany, economics, and meteorology and insurance and so on. In the case of high professional requirements, the expansion of agricultural insurance development requires emotional effort and help professionals and need of professional talents to the development of faster, stronger. But because of our province's agricultural insurance Started relatively late and lack of professional talents and the constraints of bottleneck, we need to improve the understanding of agricultural insurance talent special training and talents education attaches great importance to the agricultural insurance. We Can perform on the basis of existing staff, target training, make existing insurance practitioners in the marketing skills and improve practical operation skills, at the same time, carry out the agricultural insurance business of insurance company. And it can undertake university-enterprise cooperation with universities, dedicated to carry out the work of agricultural insurance is suitable for talent, both to ensure the insurance company of choose and employ persons needs, can also make the insurance personnel's quality is guaranteed.

\section{REFERENCES}

[1] Du Pengcheng. Research on Liaoyuan agricultural insurance development. Journal of Fujian agriculture, 2014 
[2] Zhang Xiangjun. Healthy Development on promoting the development of agricultural insurance. Rural economy of Fujian agriculture. 2014

[3] Yuan Chunwang. Some thinking and Suggestions on the development of agricultural insurance in Jilin province Jilin finance research, 2014 (12)

[4] Yang Zheng. Analysis of present situation and the development characteristic agriculture insurance in Jilin province. "Journal of Jilin province economic management cadre institute, 2015 (02)

[5] Huang Ying. The practice of China's policy-oriented agricultural insurance subsidies mechanism and innovation [J]. Journal of southwest finance, 2015. (1).

[6] Joseph: the existing problems in the development of agricultural insurance in our country and the countermeasures [J]. Journal of theory, 2015. (5).

[7] Qie Ya. The sustainable development of agricultural insurance problem research [D]. Master degree theses of master of Hebei economic and trade university, 2015.

[8] China insurance association. China's agricultural insurance market demand survey [R]. 2014.

[9] Wang Zhenjun Shen Linhao. Optimization design of policy-related agricultural insurance in China [J]. Journal of rural economy, 2015. (2). 